\title{
Neuropharmacological Profile of a Novel Potential Atypical Antipsychotic Drug Y-931 (8-fluoro-12-(4-methylpiperazin-1-yl)- $6 H$-[1]benzothieno[2,3-b][1,5] benzodiazepine maleate)
}

Toshihiko Morimoto, M.S., Kenji Hashimoto, Ph.D., Hiroshi Yasumatsu, Ph.D., Hiroshi Tanaka, Ph.D., Masatake Fujimura, Ph.D., Makoto Kuriyama, M.S, Koreichi Kimura, Ph.D., Shuzo Takehara, M.S., and Keiji Yamagami, Ph.D.

The neuropharmacological profile of Y-931, 8-fluoro-12(4-methylpiperazin-1-yl)-6H-[1]benzothieno [2,3b][1,5]benzodiazepine maleate, was investigated in comparison with those of typical and claimed atypical antipsychotic drugs. Similar to clozapine and olanzapine, Y-931 interacted with multiple neurotransmitter receptors such as dopaminergic, serotonergic, $\alpha$-adrenergic, muscarinic and histaminergic receptors. Y-931, as well as the other antipsychotics, was active in a dose-dependent manner in established tests which are indicative of potential antipsychotic activity such as inhibition of apomorphineinduced hyperactivity and suppression of conditioned avoidance responses, however, only Y-931 and clozapine were devoid of cataleptogenic potential. In models of $N$ methyl-D-aspartate (NMDA) receptor hypofunction, $Y$ -
931 demonstrated the most potent protective action against the dizocilpine-induced neurotoxicity (neuronal vacuolization) in the rat retrosplenial cortex ([Y-931 (ED $D_{50}$; $0.20 \mathrm{mg} / \mathrm{kg}$, p.o.), olanzapine (1.1), clozapine (5.7), risperidone (6.9), haloperidol (19)). Furthermore, Y-931 and clozapine, unlike the other antipsychotics used, reversed the dizocilpine-induced social deficits at the same doses at which their neuroprotective action was exhibited. The present results suggest that Y-931 may be a novel potential atypical antipsychotic drug with a low risk of extrapyramidal syndrome (EPS) and the property to ameliorate NMDA receptor hypofunction.

[Neuropsychopharmacology 26:456-467, 2002] (C) 2002 American College of Neuropsychopharmacology. Published by Elsevier Science Inc.
KEY WORDS: Y-931; Dizocilpine ((+)-MK-801); Atypical antipsychotic drugs; Schizophrenia; Glutamate; Dopamine

From the Drug Discovery Laboratories, Pharmaceutical Research Division, Welfide Corporation 7-25, Koyata 3-Chome, Iruma, Saitama, 358-0026, Japan.

Address correspondence to: Dr. Kenji Hashimoto, Welfide Corporation, 7-25 Koyata 3-Chome, Iruma, Saitama 358-0026, Japan. Tel.: +81-42-963-3121, Fax: +81-42-964-1906.

Received April 12, 2001; revised July 31, 2001; accepted August 7, 2001.

Online publication: $8 / 27 / 01$ at www.acnp.org/citations/Npp 082701163
Schizophrenia is a heterogeneous disease that comprises multiple psychological domains such as positive symptoms, negative symptoms and cognitive dysfunction. The efficacy of typical antipsychotic drugs, such as haloperidol, in treating positive symptoms correlates highly with their affinity for postsynaptic dopamine $\mathrm{D}_{2}$ receptors, suggesting that the dopamine $\mathrm{D}_{2}$ receptor might play a role in the psychotic symptoms of schizophrenia. However, a major problem associated with the use of typical antipsychotic drugs is the production of an extrapyramidal syndrome (EPS) as a result of their 
antagonism of dopaminergic projections of the nigrostriatal pathway. In addition, their poor efficacy against negative symptoms and cognitive dysfunction, as well as the existence of treatment-resistant patients presents more therapeutic limitations on their use.

Clozapine, a prototype of atypical antipsychotic drugs, appears to overcome many of the deficiencies associated with the use of typical antipsychotic drugs. It has been shown to be beneficial in approximately 30\% of patients who do not respond to typical antipsychotic therapy, without producing extrapyramidal syndrome (EPS) (Kane et al. 1988; Buchanan 1995; Ashby and Wang 1996; Meltzer et al. 1999). Despite these advantages, the clinical use of clozapine is limited because of a significant incidence of lethal agranulocytosis (Grohmann et al. 1989; Kane and McGlashan 1995; Borison 1997). Furthermore, it is known that clozapine also is associated with a range of other side effects such as weight gain, hypersalivation, sedation, cardiovascular side effects, lowering of seizure threshold (Miller 2000). Although clozapine has triggered the introduction of a number of novel antipsychotic drugs that have also claimed atypical status during the past decade, it remains controversial whether these newer agents capture the clinical uniqueness of clozapine (Kane and McGlashan 1995; Meltzer et al. 1999; Remington and Kapur 2000).

Following the domination of the dopamine hypothesis in schizophrenia, several lines of evidence have suggested that a dysfunction in glutamatergic neurotransmission might be involved in the pathophysiology of schizophrenia (Javitt and Zukin 1991; Olney and Farber 1995; Coyle 1996; Tamminga 1998; Aghajanian and Marek 2000). This hypothesis evolves from clinical findings that phencyclidine (PCP) and its congener ketamine, which block the N-methyl-D-aspartate (NMDA) receptor ion channel, induce a schizophrenia-like psychosis representing negative and positive symptoms as well as cognitive dysfunction in humans (Krystal et al. 1994; Javitt and Zukin 1991; Luby et al. 1959). This evidence has led to the extensive use of NMDA receptor antagonists in the preclinical research of schizophrenia (Javitt and Zukin 1991; Jentsch and Roth 1999; Olney and Farber 1995). Among these approaches, Olney et al. (1989) have demonstrated that NMDA receptor antagonists such as PCP and dizocilpine ((+)-MK-801) induce neuropathological changes in the rat retrosplenial cortex, which is a component of the Papez-like limbic circuit. Interestingly, it has been reported that clozapine, but not haloperidol, blocks the dizocilpine-induced neuropathological changes in the rat retrosplenial cortex at therapeutic doses (Farber et al. 1996; Fujimura et al. 2000; Hashimoto et al. 2000). The retrosplenial cortex has been shown to play a pivotal role in discriminative avoidance learning and spatial memory processes, thus the cognitive dysfunction produced by NMDA receptor antagonists may, in part, result from these neuropathological changes (Sutherland and Hoesing 1993; Maddock 1999). Therefore, determination of the potential to reverse dizocilpine-induced neuropathological changes in the rat retrosplenial cortex may provide a beneficial model for screening and evaluating therapeutic agents targeted against the negative symptoms and cognitive dysfunction associated with schizophrenia (Olney and Farber 1995; Olney et al. 1999).

In addition, it has been suggested that activity of NMDA receptors on cortical glutamatergic efferent projections affects the regulation of various neurotransmitter systems involved in a subcortical negative feedback loop. For instance, prolonged reductions in cortical activity of NMDA receptors associated with schizophrenia would diminish tonic dopamine release and possibly lead to large amplitude phasic dopamine activity in the midbrain that may drive psychotic symptoms (Carlsson and Carlsson 1990; Grace 1991). It is therefore suggested that restoration of glutamatergic neurotransmission may possibly contribute to improved therapeutic efficacy against refractory schizophrenia compared with conventional dopamine antagonists.

In the light of the above observations, we worked on the development of a compound that could suppress dopaminergic hyperactivity with a low risk of side effects as well as inhibit dizocilpine-induced neuropathological changes in the rat retrosplenial cortex. In this paper, we report a novel, potential atypical antipsychotic drug Y-931, 8-fluoro-12-(4-methylpiperazin-1-yl)-6H[1]benzothieno $[2,3-b][1,5]$ benzodiazepine maleate, with properties to ameliorate the NMDA receptor hypofunction (Figure 1).

\section{MATERIALS AND METHODS}

\section{Animals}

Male Wistar rats (Japan SLC Inc., Shizuoka, Japan), male Lister hooded rats (Seac Yoshitomi, Fukuoka, Japan) and female Sprague-Dawley rats (Japan Clea Inc., Tokyo, Japan) were housed under environmentally controlled conditions (lights on 6:00 A.M. to 6:00 P.M.; $23 \pm$

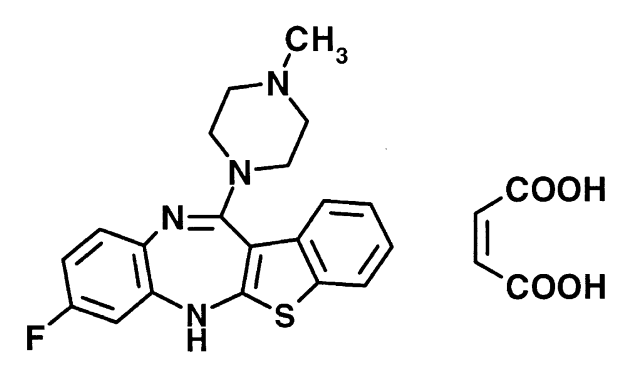

Figure 1. Chemical structure of Y-931 (8-fluoro-12-(4methylpiperazin-1-yl)-6H-[1]benzothieno $[2,3-b][1,5]$ benzodiazepine maleate). 
$3^{\circ} \mathrm{C} ; 55 \pm 20 \%$ humidity) and had access to food and water ad libitum. Details of the animals used for each experimental procedure are given below. All experiments were carried out in accordance with the Guide for the Care and Use of Laboratory Animals, Research Laboratories, Welfide Corporation.

\section{Drugs}

Y-931, olanzapine, clozapine, haloperidol and risperidone were synthesized at Welfide Corporation (Japan). Other drugs were obtained from the following sources: (-)-sulpiride, mianserin hydrochloride, prazosin hydrochloride, (-)-arterenol bitartrate, (-)-alprenolol D-tartrate hydrate, pyrilamine maleate, atropine sulfate and apomorphine hydrochloride (Sigma Chemical Co., St. Louis, MO, USA), (+)-MK-801 hydrogen maleate (dizocilpine) and fluphenazine dihydrochloride (Research Biochemicals International, Natick, MA, USA), serotonin (5-hydroxytryptamine; 5-HT) creatinine sulfate (Merck KGaA, Darmstadt, Germany), sodium pentobarbital (Nembutal ${ }^{\circledR}$ Injection) (Dainippon Pharmaceutical Co. Ltd., Osaka, Japan), [N-methyl- $\left.{ }^{3} \mathrm{H}\right]-\mathrm{SCH} 23390$ ( $\left.\left[{ }^{3} \mathrm{H}\right] \mathrm{SCH} 23390\right)$, [propyl-2,3-ring-1,2,3- $\left.{ }^{3} \mathrm{H}\right]-8$-hydroxyDPAT $\left(\left[{ }^{3} \mathrm{H}\right] 8-\mathrm{OH}-\mathrm{DPAT}\right)$, [ethyl- $\left.{ }^{3} \mathrm{H}\right]-$ ketanserin hydrochloride ([$\left.{ }^{3} \mathrm{H}\right]$ ketanserin), $\quad\left[7-\right.$ methoxy- $\left.{ }^{3} \mathrm{H}\right]$-prazosin $\left(\left[{ }^{3} \mathrm{H}\right]\right.$ prazosin), [benzene ring- $\left.{ }^{3} \mathrm{H}\right]$-clonidine hydrochloride $\left(\left[{ }^{3} \mathrm{H}\right]\right.$ clonidine), L-[benzilic- $\left.4,4^{\prime}-{ }^{3} \mathrm{H}\right]$-quinuclidinyl benzilate $\left(\left[{ }^{3} \mathrm{H}\right] \mathrm{QNB}\right)$, levo-[ring, propyl- $\left.{ }^{3} \mathrm{H}(\mathrm{N})\right]$-dihydroalprenolol hydrochloride $\left.\left({ }^{3} \mathrm{H}\right] \mathrm{DHA}\right)$, [pyridinil$\left.{ }^{5-}{ }^{3} \mathrm{H}\right]$-pyrilamine $\left(\left[{ }^{3} \mathrm{H}\right]\right.$ pyrilamine) and $(+)-\left[3-{ }^{3} \mathrm{H}\right]-\mathrm{MK}-$ $801\left(\left[{ }^{3} \mathrm{H}\right]\right.$ dizocilpine)(NEN ${ }^{\mathrm{TM}}$ Life Science Products, Inc., Boston, MA, USA), $\left[{ }^{3} \mathrm{H}\right]$ spiperone and $\left[{ }^{3} \mathrm{H}\right] \mathrm{me}-$ sulergine (Amersham Pharmacia Biotech Ltd., Buckinghamshire, UK). All other chemicals were purchased commercially. For binding assays, $2 \mathrm{mM}$ stock solutions were prepared by dissolving the appropriate weight of each test compound in $10 \%$ dimethyl sulfoxide/ $5 \mathrm{mM}$ $\mathrm{HCl}$ solution. Solutions of the required concentration were then made by dilution of this stock solution with 5 $\mathrm{mM} \mathrm{HCl}$ solution. For in vivo studies, the test compounds were dissolved or suspended in $0.5 \%$ hydroxypropylmethylcellulose (HPMC) solution and administered orally in a volume of 1 or $2 \mathrm{ml} / \mathrm{kg}$. All control groups were treated with an equal volume of HPMC solution. Unless otherwise stated, the pretreatment time was fixed as $1 \mathrm{~h}$ for Y-931, olanzapine, clozapine and risperidone while the time for haloperidol was $3 \mathrm{~h}$. Apomorphine was dissolved in $0.1 \% l$-ascorbic acid/saline solution and injected subcutaneously in a volume of $1 \mathrm{ml} / \mathrm{kg}$. Dizocilpine was dissolved in distilled water (dizocilpine-induced neuropathological changes) or saline (dizocilpine-induced social deficits), and injected subcutaneously in a volume of $1 \mathrm{ml} / \mathrm{kg}$. All dosages are expressed as being base equivalent.

\section{Radioligand Binding Assays}

Each assay was performed in duplicate by incubating aliquots of tissue preparation with the tritium ligand in the assay buffer. The tissues and assay conditions used are summarized in Table 1. The striatum, hippocampus and cerebral cortex were dissected from brains of male Wistar rats (7 weeks old, 159-193 g) which were sacrificed by decapitation. Choroid plexus was dissected from porcine brains supplied from Cosmo Bio Co. Ltd. (Tokyo, Japan). The dissected tissues were stored at $-80^{\circ} \mathrm{C}$ until use. After incubation, the membranes were rapidly filtered through Whatman GF/B glass filters. The filters were washed with ice-cold buffer, and the retained radioactivity was measured by a liquid scintillation counter (LS 6500, Beckman). The $\mathrm{IC}_{50}$ values to inhibit specific binding were estimated by non-linear regression analysis. Furthermore, the $K_{i}$ values were obtained from the Cheng-Prusoff equation: $\mathrm{K}_{\mathrm{i}}=\mathrm{IC}_{50} /$ $\left(1+C / K_{d}\right)$, where $C$ is the concentration of radioligand used, and $K_{d}$ is the dissociation constant of the radioligand. The mean of $K_{i}$ values and their $95 \%$ confidence limits were determined.

\section{Apomorphine-induced Hyperactivity and Spontaneous Locomotor Activity}

The test compounds or vehicle were administered orally to male Wistar rats (7-8 weeks old, 185-218 g, $\mathrm{n}=$ 8) $1 \mathrm{~h}$ or $3 \mathrm{~h}$ prior to subcutaneous injection of apomorphine $(0.25 \mathrm{mg} / \mathrm{kg})$. The animals were then placed individually in the locomotor activity measuring apparatus $(45 \times 45 \times 30 \mathrm{~cm}$, SCANET MV-30, Toyo Sangyo, Ltd., Toyama, Japan), equipped with infrared photocells on the $X$ and $Y$-axes, for $40 \mathrm{~min}$. The moving distance $(\mathrm{cm}$ / $40 \mathrm{~min}$ ) of the center of gravity, detected by rats' interruptions of the photocells, was used as the index of horizontal locomotor activity. As a reference, the effect of the test compounds on spontaneous locomotor was also investigated using male Wistar rats (8 weeks old, $186-222 \mathrm{~g}, \mathrm{n}=8$ ), wherein the animals were treated for $1 \mathrm{~h}$ ( $3 \mathrm{~h}$ for haloperidol) then placed in the apparatus for $20 \mathrm{~min}$. These data were analyzed by ANOVA followed by Dunnett's multiple comparison test and the $\mathrm{ED}_{50}$ values and their $95 \%$ confidence limits to suppress apomorphine-induced hyperactivity and spontaneous locomotor activity were estimated by non-linear regression analysis.

\section{Conditioned Avoidance Response (CAR)}

Male Wistar rats (20-29 weeks old, 303-459 g, $\mathrm{n}=10$ ) were subjected to the operant test chamber $(30 \times 30 \times$ $35 \mathrm{~cm})$ fitted with a pole $(2.5 \mathrm{~cm}$ in diameter $)$ in its center, and were trained to climb the pole during the presentation of a $5 \mathrm{~s}$ tone (conditioned stimulus) to avoid a 
Table 1. Conditions for Receptor Binding Assays

\begin{tabular}{|c|c|c|c|c|c|}
\hline Receptor & Tissue & ${ }^{3} \mathrm{H}$-Ligand (nM) & $\begin{array}{l}\text { Non-specific } \\
\text { binding }(\mu M)\end{array}$ & $\begin{array}{c}\text { Incubation } \\
\text { temperature and time }\end{array}$ & References \\
\hline $\mathrm{e} \mathrm{D}_{1}$ & Rat, Striatum & $\mathrm{SCH} 2$ & Flup & in & Billard et \\
\hline Dopamine $\mathrm{D}_{2}$ & Rat, Striatum & Spiperone (0.2) & (-)-Sulpiride (100) & $37^{\circ} \mathrm{C}, 20 \mathrm{~min}$ & Creese et al. 1977 \\
\hline Serotonin $5-\mathrm{HT}_{1 \mathrm{~A}}$ & Rat, Hippocampus & 8-OH-DPAT (0.2) & Serotonin (10) & $37^{\circ} \mathrm{C}, 12 \mathrm{~min}$ & Hall et al. 1985 \\
\hline Serotonin $5-\mathrm{HT}_{2 \mathrm{~A}}$ & Rat, Cerebral cortex & Ketanserin $(0.2)$ & Mianserin (10) & $37^{\circ} \mathrm{C}, 20 \mathrm{~min}$ & Leysen et al. 1982 \\
\hline Serotonin $5-\mathrm{HT}_{2 \mathrm{C}}$ & Pig, Choroid plexus & Mesulergine (1) & Mianserin (10) & $37^{\circ} \mathrm{C}, 30 \mathrm{~min}$ & Pazos et al. 1984 \\
\hline Adrenaline $\alpha_{1}$ & Rat, Cerebral cortex & Prazosin $(0.1)$ & Prazosin (1) & $25^{\circ} \mathrm{C}, 30 \mathrm{~min}$ & Greengrass \& Bremner 19 \\
\hline Adrenaline $\alpha_{2}$ & Rat, Cerebral cortex & Clonidine (1) & (-)-Arterenol (100) & $25^{\circ} \mathrm{C}, 40 \mathrm{~min}$ & U'Prichard et al. 1979 \\
\hline Adrenaline $\beta$ & Rat, Cerebral cortex & DHA (1) & (-)-Alprenolol (1) & $25^{\circ} \mathrm{C}, 15 \mathrm{~min}$ & Bylund \& Snyder, 197 \\
\hline Muscarine ACh & Rat, Cere & $\mathrm{QN}$ & Atropin & $37^{\circ} \mathrm{C}, 12 \mathrm{~min}$ & Yamamura \& Snyd \\
\hline Histamine $\mathrm{H}_{1}$ & Rat, Cerebral cortex & Pyrilamine (2) & Pyrilamine (10) & $25^{\circ} \mathrm{C}, 30 \mathrm{~min}$ & Tran et al. 1978 \\
\hline NMDA ion-channel & 1 Rat, Cerebral cortex & MK-801 (5) & $(+)-M K-801(100)$ & $30^{\circ} \mathrm{C}, 60 \mathrm{~min}$ & Yoneda \& Ogita, 1989 \\
\hline
\end{tabular}

relevant 10-s electrical foot-shock $(0.6 \mathrm{~mA})$ through the floor grid. Each session consisted of a total of 10 sequences at 2-min intervals. Rats that could complete the session with a reliability of at least $80 \%$ on the avoidance response in this procedure were subjected to the following experiments. The effect of orally administered test compounds on the acquired CAR was evaluated 1, 3, 5 and $24 \mathrm{~h}$ after their administration. These data were analyzed by ANOVA followed by Dunnett's multiple comparison test and the $\mathrm{ED}_{50}$ values and their 95\% confidence limits to suppress CAR were estimated by the non-linear regression analysis.

\section{Catalepsy}

Assessment of the cataleptogenic response was performed 1, 3, 5 and $7 \mathrm{~h}$ after oral administration of the test compounds or vehicle to male Wistar rats (8-10 weeks old, 176-248 g, $\mathrm{n}=8$ ), with the observer blind to the original treatment. Individual rats were gently placed with both forelimbs over a horizontal bar at a height of $7 \mathrm{~cm}$ and the latency for which they remained in that position (catalepsy time) was recorded for a maximum of $60 \mathrm{~s}$. Catalepsy time recorded 1, 3, 5 and 7 $\mathrm{h}$ after administration of the test compounds was thereafter summated to define 'SUM catalepsy time (sec)'. The dose at which the SUM catalepsy time reached $10 \mathrm{~s}$ was estimated as an $\mathrm{ED}_{10 \text { s }}$ value with $95 \%$ confidence limits by linear regression analysis.

\section{Dizocilpine-induced Neuropathological Changes}

The effect of the drugs on dizocilpine-induced neuropathological changes in the rat retrosplenial cortex were determined by a previously reported method (Hashimoto et al. 1997, 2000; Fujimura et al. 2000). Following oral administration of the test compounds or vehicle, female Sprague-Dawley rats (10-12 weeks old, 208-270 g, n = 4) were treated with dizocilpine (0.5 $\mathrm{mg} / \mathrm{kg}$, subcutaneously). Four hours after the dizo- cilpine injection, the animals were deeply anesthetized with sodium pentobarbital $(50 \mathrm{mg} / \mathrm{kg}$, intraperitoneally). Ten minutes later, they were transcardially perfused with $100 \mathrm{ml}$ of isotonic saline, followed by $400 \mathrm{ml}$ of Mildform ${ }^{\circledR}$ (Wako Pure Chemicals Industries, Ltd., Osaka, Japan). Subsequently, the brain was removed, processed by graded ethanol dehydration, embedded in paraffin and sectioned into 3- $\mu \mathrm{m}$ thick coronal slices and stained with hematoxylin and eosin. The number of vacuolized neurons in layers III and IV of the retrosplenial cortex of each side of the brain (bregma level$5.80 \mathrm{~mm}$ according to the atlas of rat brain (Paxinos and Watson 1997)) were counted, with the observer blind to the original treatment. The average number of vacuolized neurons from two sections was taken for each subject. These data were analyzed by ANOVA followed by Dunnett's multiple comparison test and the $\mathrm{ED}_{50}$ values and their $95 \%$ confidence limits to inhibit neuronal vacuolization were estimated by non-linear regression analysis.

\section{Dizocilpine-induced Social Deficits}

The effect of the test compounds on dizocilpine-induced social deficits, defined as a selective decrease in social interaction behaviors observed $24 \mathrm{~h}$ after the injection of dizocilpine, was investigated in the male Lister hooded rats (6-8 weeks old, 191-313 g, n = 5 pairs). The method used to observe social interaction behaviors has been previously described (Yasumatsu et al. 1994). Each pair of rats were placed in a brightly lit (1200 lux at floor level) open-topped perspex box $(51 \times$ $51 \times 30 \mathrm{~cm}$ ) with $17 \mathrm{~cm}$ square areas marked on the floor $24 \mathrm{~h}$ after subcutaneous injection of dizocilpine $(0.25 \mathrm{mg} / \mathrm{kg})$ or saline. Their behaviors were recorded over a $10 \mathrm{~min}$ period via a video camera so as to leave them undisturbed. All the test compounds or vehicle were administered orally $1 \mathrm{~h}$ before the behavioral observation ( $23 \mathrm{~h}$ after the injection of dizocilpine), with an exception of haloperidol which was administered 
$3 \mathrm{~h}$ before the testing ( $21 \mathrm{~h}$ after the injection of dizocilpine). All behavioral assessments were made from the recording, with observer blind to the original treatment. Social interaction between the rats was determined as the total time spent participating in the following behaviors: sniffing of the partner, climbing over or crawling under the partner, genital investigation of the partner and following of the partner. In addition, locomotor activity was measured as the number of line crossings marked on the floor of the test arena. Comparison between saline-vehicle and dizocilpine-vehicle groups was performed by $t$-test to confirm the incidence of social deficits. The effects of the test compounds on saline- or dizocilpine-pretreated groups were then analyzed by ANOVA followed by Dunnett's multiple comparison test.

\section{RESULTS}

\section{Radioligand Binding Assays}

As shown in Table 2, Y-931 exhibited the highest affinity for serotonin $5-\mathrm{HT}_{2 \mathrm{~A}}\left(\mathrm{~K}_{\mathrm{i}}\right.$ value of $\left.0.89 \mathrm{nM}\right)$ and $5-\mathrm{HT}_{2 \mathrm{C}}(0.89 \mathrm{nM})$ receptors followed by those for adrenaline $\alpha_{1}(1.5 \mathrm{nM})$ and dopamine $\mathrm{D}_{2}(3.0 \mathrm{nM})$ receptors. Y-931 also interacted with dopamine $\mathrm{D}_{1}$, muscarinic cholinergic, and histamine $\mathrm{H}_{1}$ receptors to a lesser extent with $\mathrm{K}_{\mathrm{i}}$ values between 10 and $36 \mathrm{nM}$, and only weakly interacted with serotonin $5-\mathrm{HT}_{1 \mathrm{~A}}$ and adrenaline $\alpha_{2}$ receptors. The multifaceted receptor binding profile of Y-931 was similar to those of olanzapine and clozapine, but not haloperidol and risperidone, which bind to fewer receptors at clinical doses compared with clozapine, olanzapine and Y-931. However, none of the test compounds appreciably displaced the labeled specific ligands for adrenaline $\beta$ receptor or the ion-channel sites of NMDA receptors.

\section{Antagonism of Apomorphine-induced Hyperactivity and Suppression of Spontaneous Locomotor Activity}

As shown in Figure 2, Y-931 and the antipsychotic drugs dose-dependently inhibited apomorphine-induced hyperactivity in rats. All the test compounds produced maximal inhibition $1 \mathrm{~h}$ after oral administration, except haloperidol, which produced maximal inhibition after $3 \mathrm{~h}$. Therefore, the pretreatment time was fixed as $1 \mathrm{~h}$ for Y-931, olanzapine, clozapine and risperidone and $3 \mathrm{~h}$ for haloperidol in subsequent procedures, unless otherwise stated.

After the respective pretreatment time, each test compound dose-dependently suppressed spontaneous locomotor activity (Figure 3 ) with $\mathrm{ED}_{50}$ values summarized in Table 3.

\section{Inhibition of CAR}

As shown in Figure 4, the maximal inhibition of CAR was evident within 1-3 $\mathrm{h}$ after the administration of Y-931, olanzapine, clozapine and risperidone after which time locomotor activity gradually returned to control levels. However, the maximal inhibitory effect of haloperidol was attained $3-5 \mathrm{~h}$ after administration. The $\mathrm{ED}_{50}$ values of the test compounds are summarized in Table 3.

\section{Induction of Catalepsy}

Control groups did not display any cataleptogenic response (SUM catalepsy time of $0 \mathrm{~s}$ ). As shown in Figure 5, Y-931 and clozapine did not cause an obvious cataleptogenic response at doses up to 250 and $100 \mathrm{mg} / \mathrm{kg}$, respectively. In contrast, olanzapine, haloperidol and risperidone induced a cataleptogenic response, in a dose-dependent manner. The $\mathrm{ED}_{10 \text { s }}$ values are summarized in Table 3.

Table 2. Binding Profiles of the Test Compounds

\begin{tabular}{|c|c|c|c|c|c|c|}
\hline \multirow[b]{2}{*}{ Receptor } & \multicolumn{6}{|c|}{ Ki values (95\% confidence limits), $\mathrm{nM}$} \\
\hline & $\mathbf{n}^{a}$ & Y-931 & Olanzapine & Clozapine & Haloperidol & Risperidone \\
\hline Dopamine $\mathrm{D}_{1}$ & 5 & $34(31-36)$ & $46(42-50)$ & $180(160-200)$ & $130(120-140)$ & $230(220-250)$ \\
\hline Dopamine $\mathrm{D}_{2}$ & 5 & $3.0(2.5-3.5)$ & $26(24-29)$ & $160(140-190)$ & $2.4(2.0-2.7)$ & $6.3(5.4-7.4)$ \\
\hline Serotonin $5-\mathrm{HT}_{1 \mathrm{~A}}$ & 5 & $270(230-320)$ & $1900(1700-2200)$ & $170(160-180)$ & $1800(1200-2600)$ & $110(100-120)$ \\
\hline Serotonin $5-\mathrm{HT}_{2 \mathrm{~A}}$ & 5 & $0.89(0.65-1.2)$ & $1.6(0.83-3.1)$ & $7.5(6.2-9.1)$ & $47(42-53)$ & $0.28(0.23-0.33)$ \\
\hline Serotonin $5-\mathrm{HT}_{2 \mathrm{C}}$ & 4 & $0.89(0.47-1.7)$ & $2.7(1.7-4.0)$ & $2.9(2.1-4.1)$ & $5700(2800-12000)$ & $22(8.6-55)$ \\
\hline Adrenaline $\alpha_{1}$ & 5 & $1.5(1.3-1.7)$ & $9.5(8.5-11)$ & $3.2(2.6-3.9)$ & $4.4(3.6-5.4)$ & $0.48(0.27-0.85)$ \\
\hline Adrenaline $\alpha_{2}$ & 5 & $320(250-400)$ & $1100(880-1300)$ & $210(180-260)$ & $>10000^{b}$ & $13(8.2-19)$ \\
\hline Adrenaline $\beta$ & 3 & $>10000^{b}$ & $>10000^{b}$ & $>10000^{b}$ & $>10000^{b}$ & $>10000^{b}$ \\
\hline Muscarine ACh & 5 & $10(11-12)$ & $38(41-47)$ & $42(46-52)$ & $>10000^{b}$ & $>10000^{b}$ \\
\hline Histamine $\mathrm{H}_{1}$ & 5 & $36(30-42)$ & $26(12-57)$ & $24(12-47)$ & $2900(2100-3900)$ & $160(110-250)$ \\
\hline NMDA ion-channel & 3 & $>10000^{b}$ & $>10000^{b}$ & $>10000^{b}$ & $>10000^{b}$ & $>10000^{b}$ \\
\hline
\end{tabular}

${ }^{a}$ Number of separate experiments

${ }^{b} \mathrm{IC}_{50}$ values 

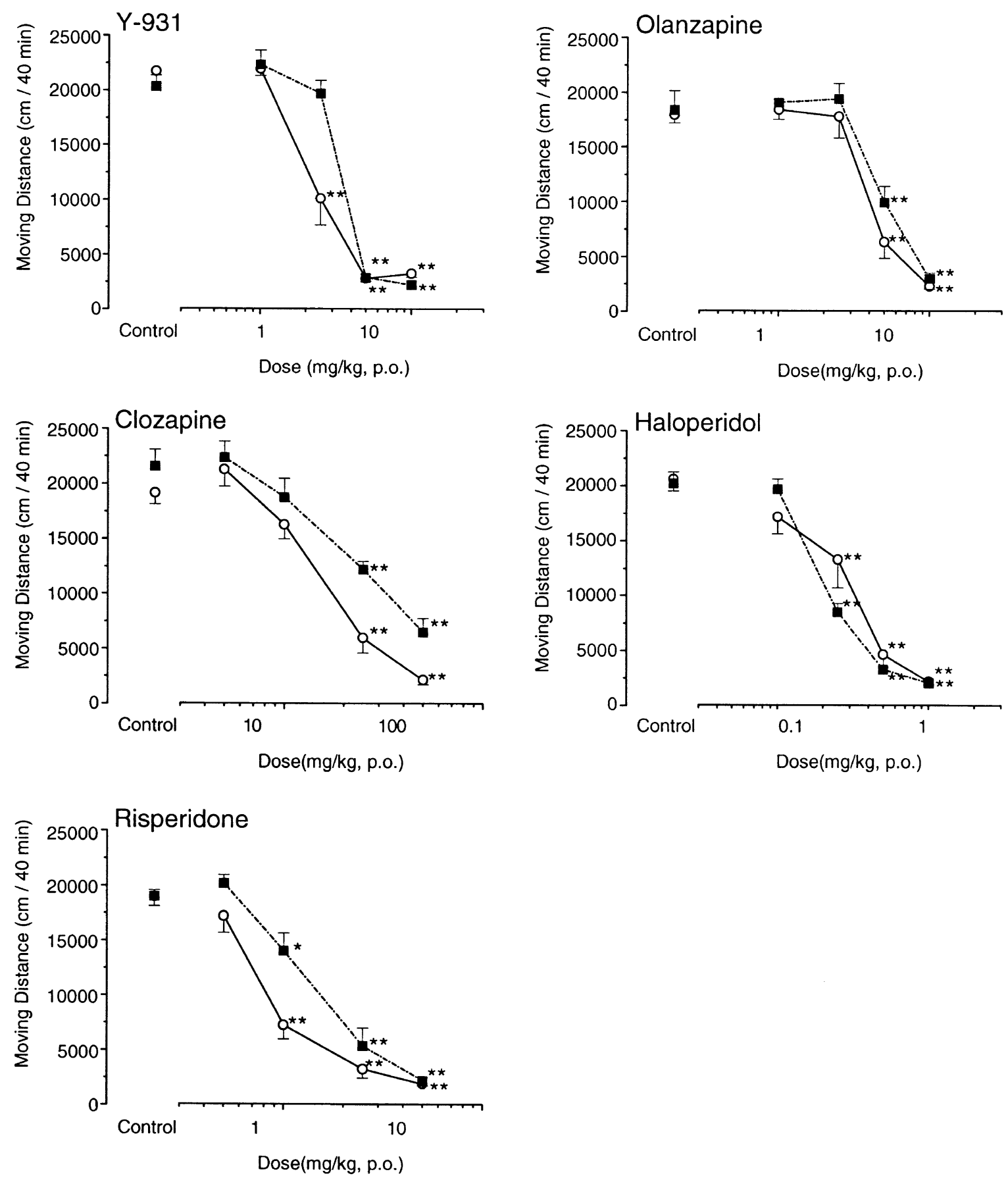

Figure 2. Inhibition of apomorphine-induced hyperactivity in rats. Dose-response curves for antagonism of apomorphine $(0.25 \mathrm{mg} / \mathrm{kg}$, s.c.)-induced hyperactivity in rats. Open circles and closed squares indicate the 1 and $3 \mathrm{~h}$ pretreatment, respectively. Data is expressed as the mean \pm S.E.M. of eight rats. ${ }^{*} p<.05,{ }^{* *} p<.01$ as compared with vehicle treated group (Dunnett's multiple comparison test).

\section{Inhibition of Dizocilpine-induced Neuropathological Changes}

As shown in Figure 6, the test compounds protected against dizocilpine-induced neurotoxicity in the rat retrosplenial cortex, in a dose dependent manner. Y-931 demonstrated the most potent protective action among the test compounds. The $\mathrm{ED}_{50}$ values are summarized in Table 3.

\section{Antagonism of Dizocilpine-induced Social Deficits}

Pretreatment with dizocilpine $24 \mathrm{~h}$ before the observation period induced a drastic decrease in social interac- 


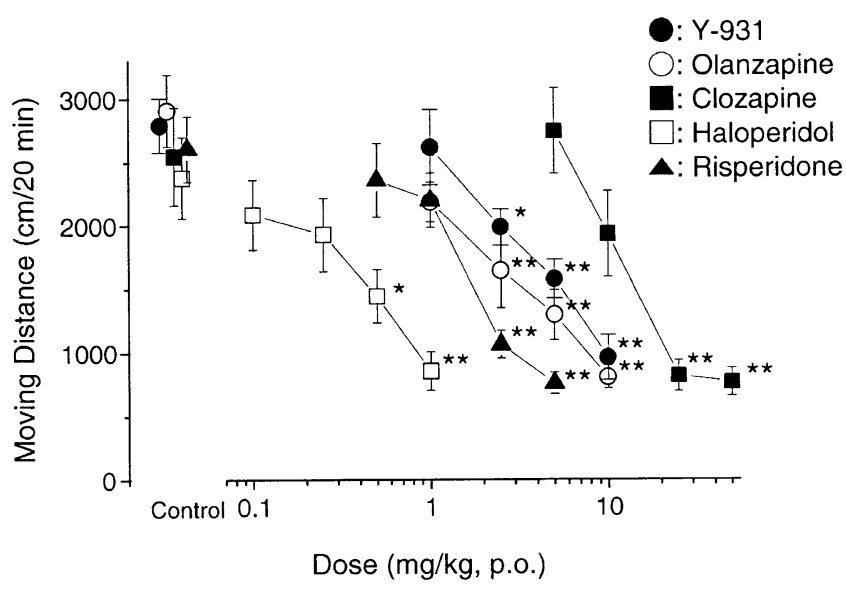

Figure 3. Suppression of spontaneous locomotor activity in rats. Data is expressed as the mean \pm S.E.M. of 8 rats. ${ }^{*} p$ $<.05{ }^{* *} p<.01$ as compared with control group (Dunnett's multiple comparison test).

tion behaviors without affecting locomotor activity in all control groups (Figure 7). Y-931 significantly reversed the social deficits in dizocilpine-pretreated rats at a dose of $0.25 \mathrm{mg} / \mathrm{kg}$ and above. Clozapine produced similar reversal at doses of 5 and $10 \mathrm{mg} / \mathrm{kg}$. However, olanzapine, haloperidol and risperidone failed to restore the dizocilpine-induced deficits at any of the doses tested. A shortening of social interaction time was observed with all the test compounds at doses that produced a sedative effect (defined as a decrease in the number of line crossings compared with saline treated rats).

\section{DISCUSSION}

The present study suggests that Y-931 may be a novel potential atypical antipsychotic drug with a low risk of EPS and the property to ameliorate NMDA receptor hypofunction. In vitro receptor binding assays indicate that Y-931 shares similar binding properties with clozapine and olanzapine from a view point of the multiple receptor interactions. Available evidence suggests that the unique atypical profile of clozapine cannot be at- tributed to action at a single receptor but is more likely to be due to combined activity at some or all of the various neurotransmitter receptors including dopaminergic, serotonergic, $\alpha$-adrenergic, muscarinic and histaminergic receptors (Ashby and Wang 1996; Bymaster et al. 1997). The high affinity of atypical antipsychotics for 5 -HT receptors has received much focus in the past decade. It is believed that the ability of 5-HT to modulate dopaminergic function provides a viable mechanism for enhanced efficacy of antipsychotics in schizophrenia (Kapur and Remington 1996; Meltzer and Fatemi 1996). On this basis, it is possible that Y-931, which possesses higher affinity for $5-\mathrm{HT}_{2 \mathrm{~A} / 2 \mathrm{C}}$ than $\mathrm{D}_{1 / 2}$ receptors, may exert superior efficacy to haloperidol, a predominant $\mathrm{D}_{2}$ receptor ligand.

Y-931, as well as the other antipsychotic drugs, was active in a dose-dependent manner in conventional tests indicative of potential antipsychotic activity such as inhibition of apomorphine-induced hyperactivity and suppression of CAR. The relative potencies of the test compounds in the both tests support previous findings (Arnt 1982). However, it is notable that clozapine demonstrated equipotent suppression of locomotor activity in the presence or absence of the dopaminergic agonist, which may reflect its problematic incidence of sedation at therapeutic dosages (Buchanan 1995; Grohmann et al. 1989).

The most significant adverse consequence of the dopamine receptor blockade is EPS, which is the major term used to define "atypicality" of antipsychotic drugs. The present study highlights that Y-931, despite having high affinity for dopamine $\mathrm{D}_{2}$ receptors, is devoid of cataleptogenic potential. This property is similar to that of clozapine whereas olanzapine, risperidone and haloperidol caused apparent catalepsy in a dosedependent manner. In humans, clozapine is considered to have a minimal risk of EPS, as evidenced when compared with both low and high-potency conventional antipsychotic drugs (Buchanan et al. 1998; Kane et al. 1988; Pickar et al. 1992; Rosenheck et al. 1997) while the available data on olanzapine and risperidone, though not definitive, show they have little superiority over low-potency antipsychotic drugs (Remington and

Table 3. Comparison of the Test Compounds in Various Pharmacological Tests

\begin{tabular}{|c|c|c|c|c|c|c|}
\hline \multirow[b]{2}{*}{ Test (Pretreatment time) } & \multicolumn{6}{|c|}{$\mathrm{ED}_{50}$ or $\mathrm{ED}_{10 \mathrm{~s}}$ values $(95 \%$ confidence limits), $\mathrm{mg} / \mathrm{kg}$, p.o. } \\
\hline & Indice & Y-931 (1 hr) & Olanzapine (1 hr) & Clozapine (1 hr) & Haloperidol (3 hr) & Risperidone (1 hr) \\
\hline $\mathrm{APO}$ & $\mathrm{ED}_{50}$ & $2.4(1.9-2.9)$ & $2.1(1.6-2.5)$ & $18(14-22)$ & $0.23(0.20-0.26)$ & $0.91(0.74-1.1)$ \\
\hline $\mathrm{SPO}$ & $\mathrm{ED}_{50}$ & $5.8(3.8-9.0)$ & $3.6(2.0-6.4)$ & $19(11-31)$ & $0.70(0.38-1.4)$ & $2.3(1.5-3.4)$ \\
\hline CAR & $\mathrm{ED}_{50}$ & $6.2(4.7-7.6)$ & $4.3(3.8-4.8)$ & $20(15-26)$ & $0.86(0.80-0.93)$ & $3.6(2.5-4.8)$ \\
\hline CAT & $\mathrm{ED}_{10 \mathrm{~s}}$ & $>250$ & $19(13-25)$ & $>100$ & $1.5(1.2-1.8)$ & $12(9.6-15)$ \\
\hline DIN & $\mathrm{ED}_{50}$ & $0.20(0.13-0.29)$ & $1.1(0.76-1.4)$ & $5.7(4.6-7.0)$ & $19(13-30)$ & $6.9(5.3-8.9)$ \\
\hline
\end{tabular}

$\mathrm{APO}$, apomorphine-induced hyperactivity; SPO, spontaneous locomotor activity; CAR, condition avoidance response; CAT, catalepsy; DIN, dizocilpine-induced neuropathological changes. 

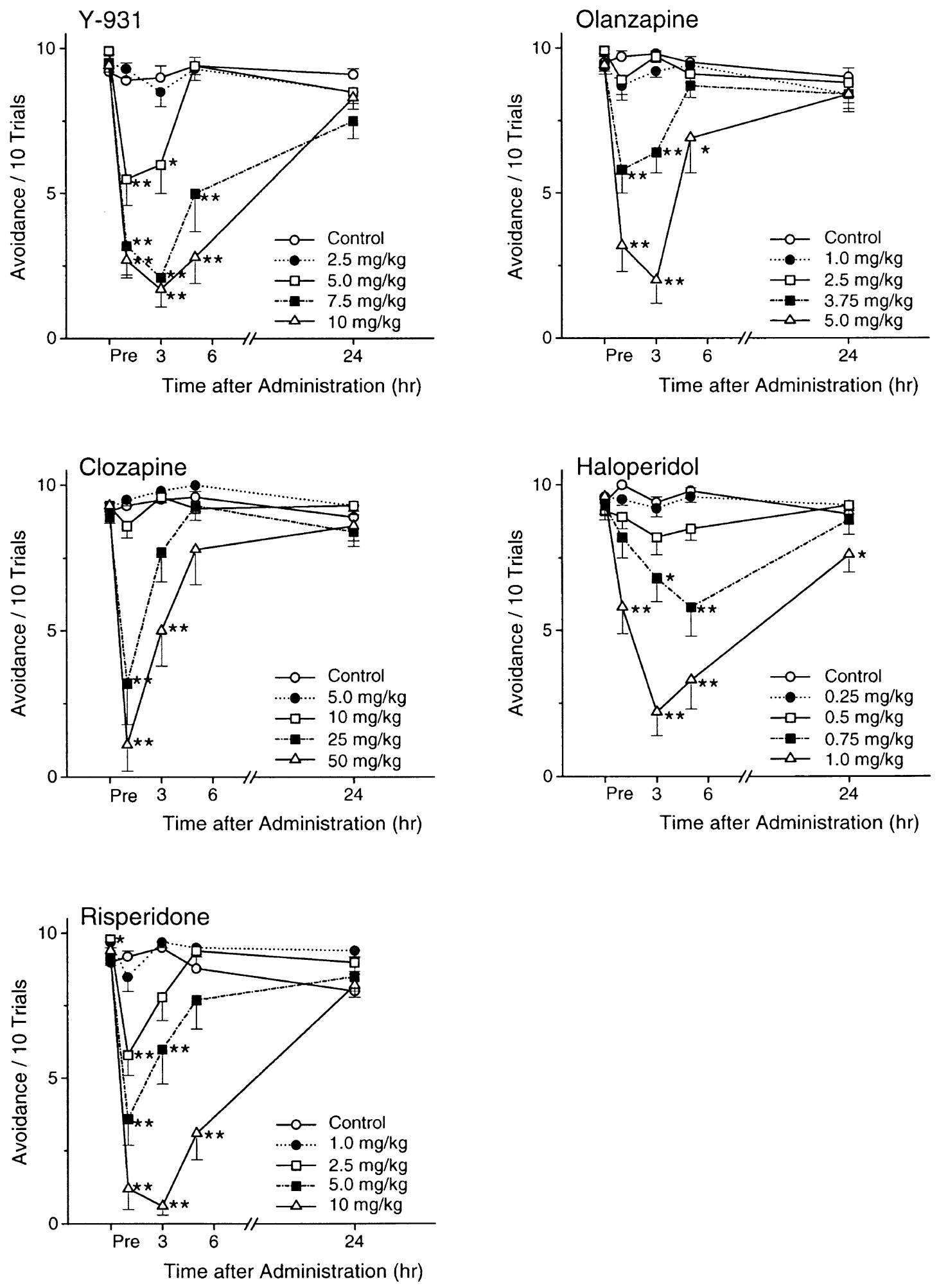

Figure 4. Inhibition of conditioned avoidance response (CAR) in rats. The inhibition of CAR was examined $1,3,5$ or $24 \mathrm{~h}$ after administration of Y-931 and antipsychotic drugs. Data is expressed as the mean \pm S.E.M. of 10 rats. ${ }^{*} p<.05,{ }^{* *} p<.01$ as compared with vehicle treated group (Dunnett's multiple comparison test). 


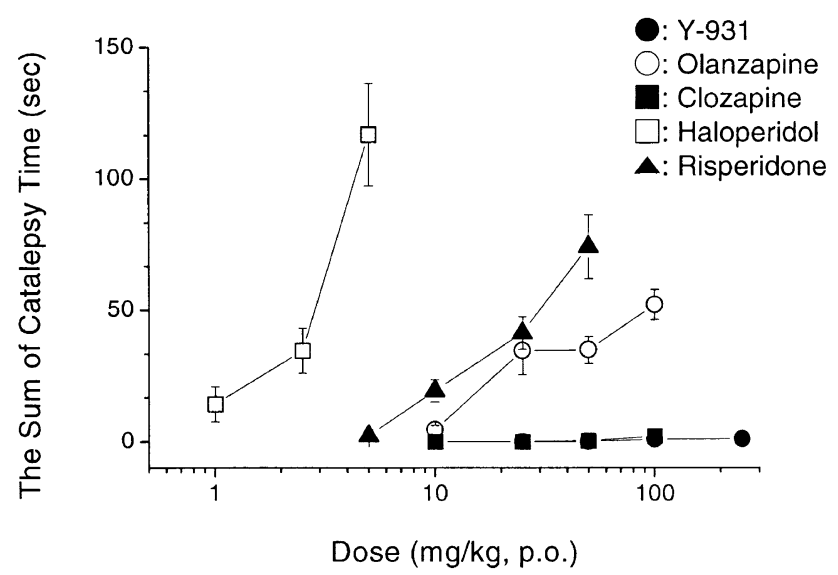

Figure 5. Induction of catalepsy in rats. Dose-response curves for Y-931 and antipsychotic drugs to induce catalepsy in rats. Data is expressed as the mean \pm S.E.M. of eight rats.

Kapur 2000). It is therefore possible that Y-931 shares the benefit of a low risk of EPS with clozapine. Although the precise mechanism(s) underlying the lack of cataleptogenic activity of Y-931 are currently unclear, one possibility is its interactions with some or all of various neurotransmitter receptors as mentioned above. The alternative is its limbic selectivity; in fact, a recent electrophysiological study has revealed that chronic administration of Y-931 decreases the number of spontaneously active dopamine cells in the ventral tegmental area (A10) without affecting cells in the substantia nigra (A9) (Minabe and Ashby, unpublished observation), suggesting its analogous limbic selectivity to clozapine (White and Wang 1983).

In models of NMDA receptor hypofunction, Y-931 was a potent inhibitor against dizocilpine-induced neurotoxicity (neuronal vacuolization) in the rat retrosplenial cortex. Its protective action was most potent among the test compounds investigated and was observed at a lower dose than those which demonstrated the robust activity in other conventional behavioral paradigms as mentioned above. In contrast, the present study revealed that haloperidol and risperidone required much higher doses to inhibit dizocilpine-induced neurotoxicity compared with those required to inhibit apomorphine-induced hyperactivity and CAR and those which produce catalepsy, suggesting that haloperidol and risperidone lack the potential to restore glutamatergic neurotransmission at therapeutic dosages as has been previously described (Fujimura et al. 2000). This is supported by clinical evidence that clozapine, but not haloperidol, blunts ketamine-induced psychosis in humans (Malhotra et al. 1997; Krystal et al. 1999) and that typical antipsychotic drugs are not efficacious against PCP-induced psychosis (Allen and Young 1978). Taken together, it seems that Y-931 might be useful for treating positive symptoms that

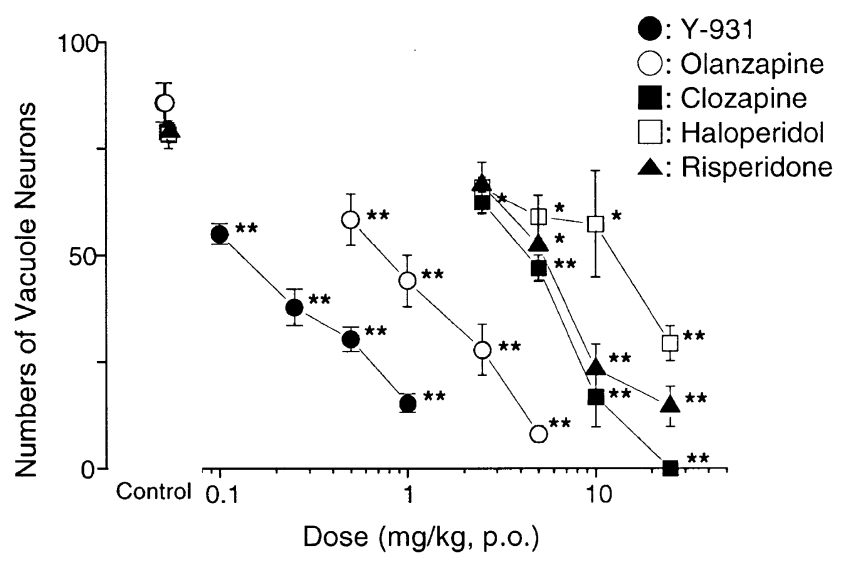

Figure 6. Inhibition of dizocilpine-induced neuropathological changes. Dose-response curves for antagonism of dizocilpine $(0.5 \mathrm{mg} / \mathrm{kg}$, s.c.)-induced neuropathological changes (neuronal vacuolization) in the retrosplenial cortex. Data is expressed as the mean \pm S.E.M. of four rats. ${ }^{*} p<.05,{ }^{* *} p<$ .01 as compared with vehicle treated group (Dunnett's multiple comparison test).

do not respond dopamine $\mathrm{D}_{2}$ receptor antagonist treatment and for treating negative symptoms in schizophrenia. Therefore, it is predicted that Y-931 may display a unique antipsychotic profile in clinical use.

It has been hypothesized that blockade of NMDA receptors triggers a complex network disturbance featuring inactivation of inhibitory neurons and consequent disinhibition of excitatory pathways as the core mechanism by which NMDA receptor antagonists cause neuronal injury in the various corticolimbic neurons (Olney and Farber 1995; Olney et al. 1999). Furthermore, it has been reported that muscarinic receptor antagonists, such as scopolamine, protect against the neurotoxicity induced by NMDA receptor antagonists in the retrosplenial cortex, suggesting a role for muscarinic acetylcholine receptors in mediating NMDA antagonistinduced neurotoxicity (Olney and Farber 1995; Olney et al. 1991, 1999). Similar to clozapine and olanzapine, Y-931 binds to muscarinic acetylcholine receptors with high affinity. Therefore, it seems that the blockade of muscarinic acetylcholine receptors by Y-931 might, in part, contribute to the protection of dizocilpine-induced neurotoxicity. It has been suggested that several receptors may be critical for conferring protection against the neuronal injury induced by NMDA receptor antagonists, as clozapine and olanzapine interact with a wide range of many neurotransmitter receptors (Olney et al. 1999). It is currently unclear whether any of the above pharmacological characteristics, or some combination thereof, account for the unique efficacy of these drugs. Further detailed studies will be necessary to clarify the mechanism underlying the ability of Y-931 to prevent dizocilpine-induced neuropathological changes in the retrosplenial cortex. 

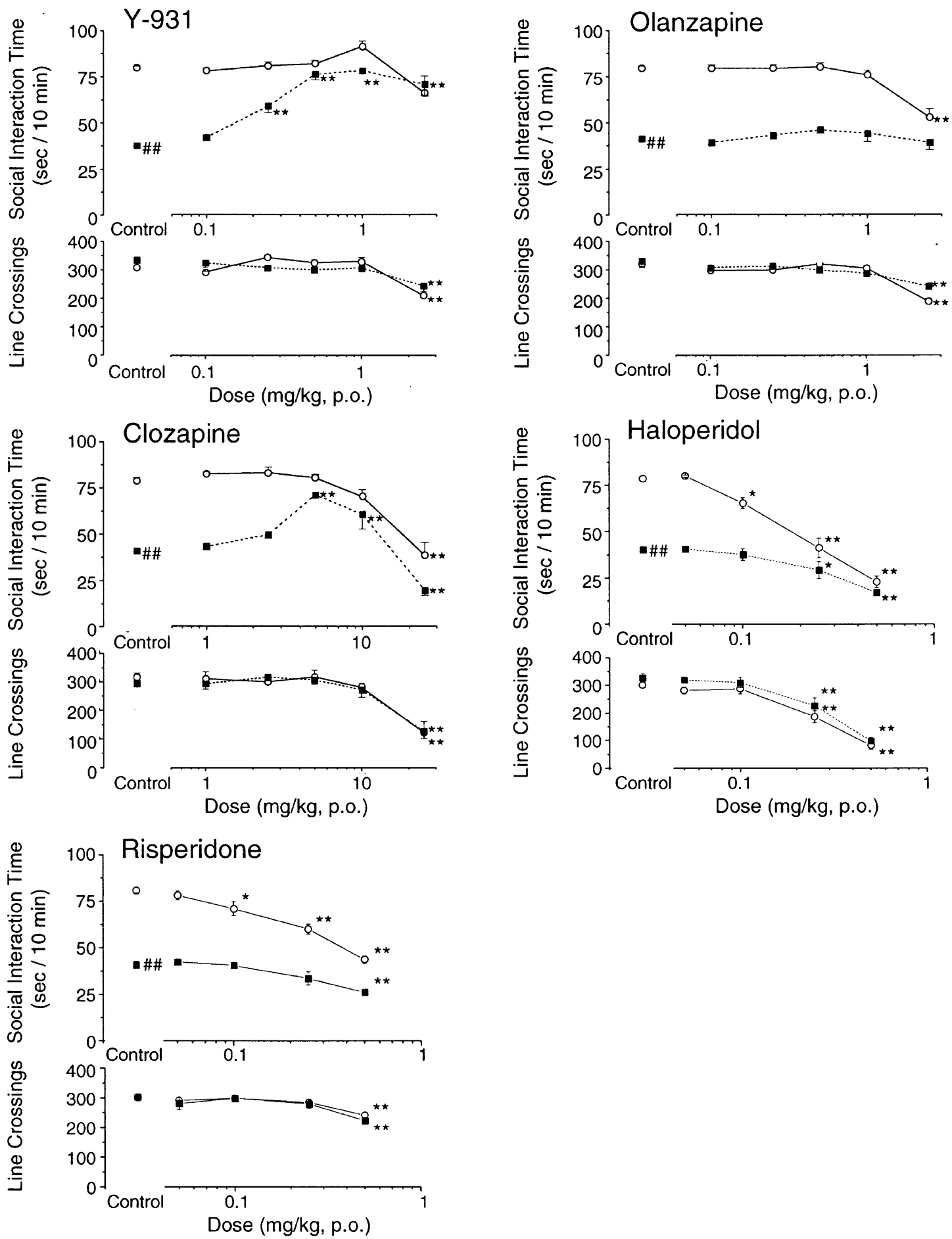

Figure 7. Antagonism of dizocilpine-induced social deficits. The effects of Y-931 and antipsychotic drugs on social interaction in saline and dizocilpine $(0.25 \mathrm{mg} / \mathrm{kg}$, s.c.) pretreated rats were examined, as described in methods. Open circles and closed squares indicate the saline and dizocilpine pretreatment, respectively. Data is expressed as the mean \pm S.E.M. of five pairs of rats. ${ }^{*} p<.05,{ }^{* *} p<.01$ as compared with vehicle treated group (Dunnett's multiple comparison test). ${ }^{\# \#} p<.01$ as compared with saline-pretreated vehicle-treated group ( $t$-test).

The present study also revealed that Y-931, as well as clozapine, antagonized the social deficits induced by dizocilpine at doses similar to those which exhibit their neuroprotective action whereas this was not observed for the other antipsychotics tested. Interestingly, although olanzapine potently inhibited dizocilpine-induced neurotoxicity, it failed to ameliorate dizocilpine-induced social deficits. One possible explanation is that olanzap- 
ine possesses a greater propensity toward causing sedation, as evidenced by decreased spontaneous locomotor activity, which may have interfered with social interaction behaviors in this paradigm. An alternative explanation is that a high affinity for dopamine receptors might interfere with the expression of any beneficial effects that olanzapine may exert through other receptors, in a manner similar to clozapine and Y-931, in reversing dizocilpine-induced social deficits. It should be noted that haloperidol and risperidone, with high affinity for dopamine $\mathrm{D}_{2}$ receptors, also did not reverse the dizocilpine-induced social deficits. Although Y-931 has high affinity for dopamine $\mathrm{D}_{2}$ receptors, it has a four-fold greater affinity for muscarinic receptors compared with olanzapine, which might confer the greater potency of Y-931 against dizocilpine-induced effects. This postulation is supported by the fact that only Y-931 and clozapine shared the property of displaying activity against dizocilpine-induced neurotoxicity and social deficits at much lower doses than those displaying activity against apomorphine-induced hyperactivity. The difference in efficacy in restoring dizocilpine-induced abnormalities should be further investigated.

In conclusion, the present study suggests the possible atypical antipsychotic property of Y-931. Y-931 was active in conventional tests indicative of potential antipsychotic activity such as inhibition of apomorphineinduced hyperactivity and suppression of CAR but was devoid of the cataleptogenic potential. Furthermore, Y-931 was indicated to possess a potent ability to ameliorate the NMDA receptor hypofunction in models such as dizocilpine-induced neurotoxicity and social deficits. These results demonstrate that the overall neuropharmacological profile of Y-931 closely resembles that of clozapine, especially within the animal models of NMDA receptor hypofunction, which suggests that Y-931 may possess a distinctive and promising profile for the improved treatment of schizophrenia with a low risk of EPS.

\section{ACKNOWLEDGMENTS}

We thank Mr. H. Shoji and Ms. M. Yamamoto, S. Takeshita and F. Matsugaki for excellent technical assistance.

\section{REFERENCES}

Aghajanian GK, Marek GJ (2000): Serotonin model of schizophrenia: emerging role of glutamate mechanisms. Brain Res Rev 31:302-312

Allen RM, Young SJ (1978): Phencyclidine-induced psychosis. Am J Psychiatry 135:1081-1084

Arnt J (1982): Pharmacological specificity of conditioned avoidance response inhibition in rats: inhibition by neu- roleptics and correlation to dopamine receptor blockade. Acta Pharmacol Toxicol 51:321-329

Ashby Jr CR, Wang RY (1996): Pharmacological actions of the atypical antipsychotic drug clozapine: a review. Synapse 24:349-394

Billard W, Ruperto V, Crosby G, Iorio LC, Barnett A (1984): Characterization of the binding of ${ }^{3} \mathrm{H}-\mathrm{SCH} 23390$, a selective D-1 receptor antagonist ligand, in rat striatum. Life Sci 35:1885-1893

Borison RL (1997): Recent advances in the pharmacotherapy of schizophrenia. Harv Rev Psychiatry 4:255-271

Buchanan RW (1995): Clozapine: efficacy and safety. Schizophr Res 21:579-591

Buchanan RW, Brier A, Kirkpatrick B, Ball P, Carpenter Jr WT (1998): Positive and negative symptom response to clozapine in schizophrenic patients with and without deficit syndrome. Am J Psychiatry 155:751-760

Bylund DB, Snyder SH (1976): Beta adrenergic receptor binding in membrane preparations from mammalian brain. Mol Pharmacol 12:568-580

Bymaster FP, Rasmussen K, Calligaro DO, Nelson DL, DeLapp NW, Wong DT, Moore NA (1997): In vitro and in vivo biochemistry of olanzapine: a novel, atypical antipsychotic drugs. J Clin Psychiatry 58(suppl 10):28-36

Carlsson M, Carlsson A (1990): Interaction between glutamatergic and monoaminergic systems within the basal ganglia-implications for schizophrenia and Parkinson's disease. Trends Neurosci 13:272-276

Coyle JT (1996): The glutamatergic dysfunction hypothesis for schizophrenia. Harv Rev Psychiatry 3:241-253

Creese L, Schneider R, Snyder SH (1977): ${ }^{3} \mathrm{H}-$ Spiroperidol labels dopamine receptors in pituitary and brain. Eur J Pharmacol 46:377-381

Farber NB, Foster J, Olney JW (1996): Olanzapine and fluperlapine mimic clozapine in preventing MK-801 neurotoxicity. Schizophr Res 21:33-37

Fujimura M, Hashimoto K, Yamagami K (2000): Effects of antipsychotic drugs on neurotoxicity, expression of foslike protein and $c$-fos mRNA in the retrosplenial cortex after administration of dizocilpine. Eur J Pharmacol 398:1-10

Greengrass P, Bremner R (1979): Binding characteristics of ${ }^{3} \mathrm{H}$-prazosin to rat brain $\beta$-adrenergic receptors. Eur J Pharmacol 55:323-326

Grace AA (1991): Phasis versus tonic dopamine release and the modulation of dopamine system responsivity: a hypothesis for the etiology of schizophrenia. Neurosci 41:1-24

Grohmann R, Rüther E, Sassim N, Schmidt LG (1989): Adverse effects of clozapine. Psychopharmacol 99 (Suppl.):S101-104

Hall MD, El Mestikawy S, Emerit MB, Pichat L, Hamon M, Gozlan H (1985): [ $\left.{ }^{3} \mathrm{H}\right]$ 8-Hydroxy-2-(di-n-propylamino)tetralin binding to pre- and postsynaptic 5-hydroxytryptamine sites in various regions of rat brain. J Neurochem 44:1685-1696

Hashimoto K, Fujimura M, Yamagami K (2000): Dizocilpineinduced neuropathological changes in rat retrosplenial cortex are reversed by subsequent clozapine treatment. Life Sci 66:1071-1078 
Hashimoto K, Tomitaka S, Bi Y, Narita N, Minabe Y, Iyo M (1997): Rolipram, a selective phosphodiesterase type-IV inhibitor, prevents induction of heat shock protein HSP70 and hsp-70 mRNA in rat retrosplenial cortex by the NMDA receptor antagonist dizocilpine. Eur J Neurosci 9:1891-1901

Javitt DC, Zukin SR (1991): Recent advances in the phencyclidine model of schizophrenia. Am J Psychiatry 148:1301-1308

Jentsch JD, Roth RH (1999): The neuropsychopharmacology of phencyclidine: from NMDA receptor hypofunction to the dopamine hypothesis of schizophrenia. Neuropsychopharmacol 20:201-225

Kane J, Honigfeld G, Singer J, Meltzer H (1988): Clozapine for the treatment-resistant schizophrenic. A doubleblind comparison with chlorpromazine. Arch Gen Psychiatry 45:789-796

Kane JM, McGlashan TH (1995): Treatment of schizophrenia. Lancet 346:820-825

Krystal JH, D'Souza DC, Karper LP, Bennett A, AbiDargham A, Abi-Saab D, Cassello K, Bowers MB, Vegso S, Henninger GR, Charney DS (1999): Interactive effects of subanesthetic ketamine and haloperidol in healthy humans. Psychopharmacol 145:193-204

Krystal JH, Karper L, Pseibyl JP, Freeman GK, Delaney R, Bremmer JD, Heninger GR, Bowers MB, Charney DS (1994): Subanesthetic effects of the noncompetitive NMDA antagonist, ketamine, in human. Arch Gen Psychiatry 51:199-214

Kapur S, Remington G (1996): Serotonin-dopamine interaction and its relevance to schizophrenia. Am J Psychiatry 153:466-476

Luby ED, Cohen BD, Rosenbaum G, Gottilieb JS, Kelly R (1959): Study of a new schizophrenomimetic drug - sernyl. Arch Neurol Psychiatry 81:363-369

Leysen JE, Niemegeers CJE, Van Nueten JM, Laduron PM (1982): $\left[{ }^{3} \mathrm{H}\right]$ Ketanserin (R41468), a selective ${ }^{3} \mathrm{H}$-ligand

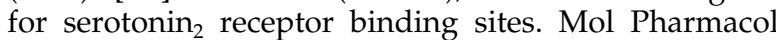
21:301-314

Maddock RJ (1999): The retrosplenial cortex and emotion: new insights from functional neuroimaging of the human brain. Trends Neurosci 22:310-316

Malhotra AK, Adler CM, Kennison SD, Elman J, Pickar D, Breier A (1997): Clozapine blunts N-methyl-D-aspartate antagonist-induced psychosis: a study with ketamine. Biol Psychiatry 42:664-668

Meltzer HY, Fatemi SH (1996): The role of serotonin in schizophrenia and the mechanism of action of antipsychotic drugs. In Kane JM, Moller HY, Awouters F (eds), Serotonin in Antipsychotic Treatment: Mechanisms and Clinical Practice. New York, Marcel Dekker, Inc., pp 77-107

Meltzer HY, Park S, Kessler R (1999): Cognition, schizophrenia, and the atypical antipsychotic drugs. Proc Natl Acad Sci USA 96:13591-13593

Miller DD (2000): Review and management of clozapine side effects. J Clin Psychiatry 61(suppl 8):14-17

Olney JW, Farber NB (1995): Glutamate receptor dysfunction and schizophrenia. Arch Gen Psychiatry 52:998-1007
Olney JW, Labruyere L, Price MT (1989): Pathological changes induced in cerebrocortical neurons by phencyclidine and related drugs. Science 244:1360-1362

Olney JW, Labruyere L, Wang G, Wozniak DF, Price MT, Sesma MA (1991): NMDA antagonist neurotoxicity: mechanism and prevention. Science 254:1515-1518

Olney JW, Newcomer JW, Farber NB (1999): NMDA receptor hypofunction model of schizophrenia. J Psychi Res 33:523-533

Paxinos G, Watson C (1997): The Rat Brain in Stereotaxic Coordinates. San Diego, Academic Press

Pazos A, Hoyer D, Palacios JM (1984): The binding of serotonergic ligands to the porcine choroid plexus: characterization of a new type of serotonin recognition site. Eur J Pharmacol 106:539-546

Pickar D, Owen RR, Litman RE, Konicki PE, Gutierrez R, Rapaport MH (1992): Clinical and biogenic response to clozapine in patients with schizophrenia: crossover comparison with fluphenazine. Arch Gen Psychiatry 49:345-353

Remington G, Kapur S (2000): Atypical antipsychotics: are some more atypical than others? Psychopharmacol 148:3-15

Rosenheck R, Cramer J, Xu W, Thomas J, Henderson W, Frisman L, Fye C, Charney D (1997): A comparison of clozapine and haloperidol in hospitalized patients with refractory schizophrenia. Department of Veterans Affairs Cooperative Study Group on Clozapine in Refractory Shizophrenia. New England J Med 337: 809-815

Sutherland RJ, Hoesing JM (1993): Posterior cingulate cortex and spatial memory: a microlimnology analysis. In Vogt BA, Gabriel M (eds), Neurobiology of Cingulate Cortex and Limbic Thalamus. Boston, Birkhauser, pp 461-477

Tamminga CA (1998): Schizophrenia and glutamatergic transmission. Cri Rev Neurobiol 12:21-36

Tran VT, Chang RSL, Snyder SH (1978): Histamine $\mathrm{H}_{1}$ receptors identified in mammalian brain membranes with [ $\left.{ }^{3} \mathrm{H}\right]$ mepyramine. Proc Natl Acad Sci USA 75:6290-6294

U'Prichard DC, Bechtel WD, Rouot BM, Snyder SH (1979): Multiple apparent alpha-noradrenergic receptor binding sites in rat brain: Effect of 6-hydroxydopamine. Mol Pharmacol 16: 47-60

White FJ, Wang RY (1983): Differential effects of classical and atypical antipsychotic drugs on A9 and A10 dopamine neurons. Science 221:1054-1057

Yamamura HI, Snyder SH (1974): Muscarinic cholinergic receptor binding in the longitudinal muscle of the guinea pig ileum with $\left[{ }^{3} \mathrm{H}\right]$ quinuclidinyl benzilate. Mol Pharmacol 10:861-867

Yasumatsu H, Morimoto Y, Yamamoto Y, Takehara S, Fukuda T, Nakao T, Setoguchi M (1994): The pharmacological properties of Y-23684, a benzodizapine receptor partial agonist. Bri J Pharmacol 111:1170-1178

Yoneda Y, Ogita K (1989): Labeling of NMDA receptor channels by $\left[{ }^{3} \mathrm{H}\right] \mathrm{MK}-801$ in brain synaptic membranes treated with Triton X-100. Brain Res 499:305-314 